\title{
Pathogenicity of Fungi Associated with Stem Cankers of Eucalypts in Tasmania, Australia
}

Z. Q. Yuan and C. Mohammed, Department of Agricultural Science, University of Tasmania, GPO Box 252-54, Hobart, Tas. 7001, Australia, and CSIRO Forestry and Forest Products, Tasmanian Research Centre, GPO Box 25212, Hobart, Tas. 7001, Australia

\begin{abstract}
Yuan, Z. Q., and Mohammed, C. 1999. Pathogenicity of fungi associated with stem cankers of eucalypts in Tasmania, Australia. Plant Dis. 83:1063-1069.

Thirteen stem-infecting fungal species, 11 from Tasmania and 2 from other parts of southeast Australia, were tested for their pathogenicity on 12-month-old seedlings of Eucalyptus nitens and E. globulus. They were classified into three groups based on their ability to cause stem canker lesions following artificial inoculation: pathogenic species (Phoma sp., Endothia gyrosa, and Seiridium eucalypti), intermediate or weakly pathogenic species (Botryosphaeria sp., Seiridium papillatum, Pestalotiopsis neglecta, Zythiostroma sp., Ceuthospora innumera, Cytospora eucalypticola, and Wuestneia epispora), and nonpathogenic species (Dinemasporium strigosum, Seiridium unicorne, and Harknessia aff. eucalypti). The potential threat of canker fungi, especially Endothia gyrosa, to plantation forestry in Australia is discussed.
\end{abstract}

The forest industry in Australia is increasingly applying more intensive silvicultural practices to timber production such as thinning in natural forest and establishing plantations. Western Australia and Tasmania are the two principal hardwood plantation centers in Australia. By 1998, there were about 120,110 ha of plantation eucalypts established in Western Australia and 78,024 ha in Tasmania (7). Over the next 5 years, Tasmania aims to establish 20,000 ha of new eucalypts for solid wood. In Tasmania, priority is being given to developing a cost-effective means of conducting health surveys in these relatively new management systems. Higher cost of intensive management means that agents resulting in stem defect, such as canker fungi, could have a significant negative impact.

Canker fungi are generally recognized as weak or opportunist pathogens on eucalypts in native forests in Australia (18). However as Australian plantations increase in number and size, certain canker fungi could constitute a considerable problem. Cryphonectria cubensis assumed its status as a seriously damaging canker pathogen in the 1970 s in conjunction with an exponential increase in the area of eucalypt plantations in countries such as Brazil and South Africa. $(8,13)$. C. cubensis is not present in Australia, but there are other potential

Corresponding author: Z. Q. Yuan E-mail: Ziqing.Yuan@ffp.csiro.au

Accepted for publication 9 August 1999.

Publication no. D-1999-0924-01R

(C) 1999 The American Phytopathological Society candidate canker fungi that could threaten plantation forestry.

A survey of stem fungi and associated canker diseases in eucalypts was conducted in Tasmanian natural forest and plantations during 1995 and 1996 (40). A total of 209 samples representing 29 fungal species were obtained. The three species most frequently encountered were Endothia gyrosa, Cytospora eucalypticola, and Valsa sp., constituting 23.9, 20.6, and 12.9\%, respectively, of the 209 collections. They were ubiquitous, with each species found on more than 10 eucalypt species. Fungal species with low incidence but associated with severe cankers were Harknessia aff. eucalypti, Phoma sp., Seiridium eucalypti, and Zythiostroma sp.

To confirm pathogenicity of these stem cankering fungi and evaluate threats to eucalypt plantations in Tasmania, a study of the pathogenicity was conducted using artificial inoculation of seedlings of Eucalyptus nitens and E. globulus, the two principal plantation species in Tasmania.

\section{MATERIALS AND METHODS}

Fungal isolates. Eleven fungal species (Table 1), namely Ceuthospora innumera, Cytospora eucalypticola, Dinemasporium strigosum, Endothia gyrosa, Harknessia aff. eucalypti, Pestalotiopsis neglecta, Phoma sp., Seiridium eucalypti, Seiridium papillatum, Wuestneia epispora, and Zythiostroma sp., were selected from those collected based on collection frequency and canker severity. For comparison, two non-Tasmanian fungal species (isolates), Botryosphaeria sp. and Seiridium unicorne, were also included in the tests because they occur on other plant hosts in Tasmania (20).
Cultures of all the fungal isolates were maintained on potato dextrose agar (PDA) slants in universal vials, stored at $4^{\circ} \mathrm{C}$ in darkness, and subcultured every 4 months before being used for inoculation.

Seedlings. Seedlings of mixed provenance E. nitens obtained from Woodlea Field Nursery, Tasmania, were maintained in 15-cm-diameter plastic pots for 12 months before inoculation. Pots were filled with commercial potting mix containing 6 parts pine bark, 4 parts sand, 1 part peat, $45 \mathrm{~g}$ of slow-release fertilizer (Osmocote, $\mathrm{N}: \mathrm{P}: \mathrm{K}$ of $14: 6.1: 11.6), 90 \mathrm{~g}$ of fast-release Osmocote (18:4.8:8.3), $121 \mathrm{~g}$ of dolomite lime, $23 \mathrm{~g}$ of trace elements, and $13.5 \mathrm{~g}$ of iron chelate. The seeds of these plants had originated from the Australian Paper Mill (APM) forest seed orchard, Gippsland, Victoria. At the time of inoculation, mean stem diameter of the seedlings at a height of $1 \mathrm{~m}$ was approximately $12 \mathrm{~mm}$.

Three-month-old, mixed provenance seedlings of E. globulus were supplied by North Forest Products, Tasmania, from a field nursery and were transplanted into $15-\mathrm{cm}$-diameter pots filled with the same potting mix as for E. nitens. They were maintained for 9 months before inoculating. At the time of inoculation, the mean stem diameter of the seedlings at a height of $0.8 \mathrm{~m}$ was approximately $10 \mathrm{~mm}$.

The seedlings of both species were kept on benches in an open-sided shade house at CSIRO, Forestry and Forest Products, Hobart, both prior to and after inoculation. They were watered using an automatic overhead sprinkler system ( 5 times per day in summer and 3 times per day in winter, 10 to $15 \mathrm{~min}$ each time). The average temperature of Hobart is $22.5^{\circ} \mathrm{C}$ in summer and $12^{\circ} \mathrm{C}$ in winter.

Inoculation. Inoculum used for tests consisted of a mixture of wheat and rice bran combined with the fungal mycelia of the species to be tested. The inoculum was prepared with a wheat bran:rice bran:water ratio of $1: 1: 2$. The mixed wheat-rice bran was autoclaved in 150-ml flasks for $15 \mathrm{~min}$ at $120^{\circ} \mathrm{C}$. Isolates of the tested fungi were recovered from stock cultures on PDA slants and subcultured onto $3 \%$ malt extract agar (MEA) in darkness at $22^{\circ} \mathrm{C}$ for 7 days. Four disks (approximately $1 \mathrm{~cm}^{2}$ ) from the 1-week-old MEA cultures were then transferred into flasks with the autoclaved bran and grown for 9 days to provide inoculum for seedling inoculation. 
Control inoculum was the autoclaved sterile bran. and E. globulus were inoculated with the 17 isolates of the 13 species listed in Table 1. Seedlings of each tree species with similar height, stem diameter, and vigor were selected. After surface-sterilizing stems with $95 \%$ ethanol, a 3-mm-diameter hole was made to the depth of the cambium at 10 to $20 \mathrm{~cm}$ above soil level on each stem using a cork-borer. A small quantity (about $0.2 \mathrm{~cm}^{3}$ ) of inoculum was placed into each wound. Plastic film was wrapped around the wounded stem to prevent desiccation and cross-contamination of inoculated seedlings. Autoclaved fungus-free bran was placed into wounds to serve as controls.

A total of 90 seedlings [(17 isolates +1 control) $\times 5$ seedlings] were used for each eucalypt species. Five replicates (or seedlings) of each inoculation treatment were distributed into five separate blocks (benches). The seedlings were randomly arranged within each block.

Inoculations of $E$. nitens were done in January (summer) 1996, and inoculations of E. globulus were done in June (winter) 1997. The seedlings were maintained in the shade house and observed regularly.

Canker evaluation and analysis of data. Stem lesions were evaluated by assessing: (i) the presence or absence of callus around the wound, (ii) whether or not a wound completely callused over, (iii) the presence or absence of fungal sporulation in bark surrounding the inoculation point, (iv) the extent of external longitudinal spread of lesions, (v) the percentage of stem girdled by lesions, and (vi) the internal longitudinal spread of discoloration in xylem (found by cutting through the lesions longitudinally).

The measurements of external lesions on E. nitens were made twice, 2 and 7 months after inoculation. The pattern of the external lesion measurement on E. nitens for each fungal isolate at 7 months was very
Twelve-month-old seedlings of $E$. nitens

similar to that assessed 2 months after inoculation. An analysis of variance showed no significant $(P>0.05)$ differences between these two measurements, and the data of the measurement at 2 months are not presented. Accordingly, the measurements of external lesions on $E$. globulus were made only 7 months after inoculation.

Internal discoloration associated with inoculation was measured by dissecting seedlings at 7 months, and reisolations were made.

Lesion length (external and internal) and percentage of stem girdled were used as the response variables. Data were analyzed using the Minitab statistical package (14) for analyses of variance (ANOVA). Treatment means were compared using least significant difference (LSD) tests.

\section{RESULTS}

Pathogenicity of fungi on $E$. nitens seedlings. The average length of external lesions and the percentage of stem girdled were significantly different $(P \leq 0.05)$ from controls with the following fungi: Phoma sp., all isolates of S. eucalypti and Endothia gyrosa, Botryosphaeria sp., P. neglecta, S. papillatum, and Zythiostroma sp. (ECF144). Although W. epispora did not produce lesions significantly different in length from the controls, the percentage of stem girdled by this fungus was significantly $(P \leq 0.05)$ different from controls (Fig. 1). Fungi that did not produce lesions significantly different $(P \leq 0.05)$ from the controls in length or percentage of stem girdled were Ceuthospora innumera, Cytospora eucalypticola, $D$. strigosum, $H$. aff. eucalypti, S. unicorne, and Zythiostroma sp. (ECF147).

Of the 13 tested fungal species, Phoma sp. produced the longest mean lesion length (Fig. 1). Dark brown to black lesions expanded rapidly in a longitudinal direction. Two months after inoculation, the maximum lesion length recorded was $130 \mathrm{~mm}$. Lesions were sunken or flattened

Table 1. Origin of fungal isolates used for pathogenicity tests with seedlings

\begin{tabular}{|c|c|c|}
\hline Fungal species & Host & Locality \\
\hline Botryosphaeria sp. & Eucalyptus stellulata & NSW $^{\mathrm{a}}$ \\
\hline Ceuthospora innumera & E. nitens & TAS \\
\hline Cytospora eucalypticola & Eucalyptus sp. & TAS \\
\hline Dinemasporium strigosum & E. nitens & TAS \\
\hline Endothia gyrosa (TAS1) & E. nitens & TAS \\
\hline Endothia gyrosa (TAS3) & E. nitens & TAS \\
\hline Endothia gyrosa (TAS9) & E. nitens & TAS \\
\hline Harknessia aff. eucalypti & E. regnans & TAS \\
\hline Pestalotiopsis neglecta & E. nitens & TAS \\
\hline Phoma sp. & E. rubida & TAS \\
\hline Seiridium eucalypti (ECF149) & E. regnans & TAS \\
\hline Seiridium eucalypti (CF39) & E. delegatensis & TAS \\
\hline Seiridium papillatum & E. delegatensis & TAS \\
\hline Seiridium unicorne & Callitris sp. & ACT \\
\hline Wuestneia epispora & E. nitens & TAS \\
\hline Zythiostroma sp. (ECF144) & E. obliqua & TAS \\
\hline Zythiostroma sp. (ECF147) & E. obliqua & TAS \\
\hline
\end{tabular}

${ }^{\text {a }}$ ACT $=$ Australian Capital Territory, NSW = New South Wales, and TAS = Tasmania. with clearly defined margins (similar to cankers observed in field) (Fig. 2B), and with longitudinal cracks. Two seedlings inoculated with Phoma sp. died from girdling 2 months after inoculation. It was the only fungus to completely girdle seedlings of $E$. nitens and kill seedlings.

An isolate of Endothia gyrosa (TAS1) produced the second longest mean lesion length. These lesions were significantly $(P$ $\leq 0.05$ ) shorter than those produced by Phoma sp., but significantly $(P \leq 0.05)$ longer than those produced by $S$. eucalypti and by the other two isolates of Endothia gyrosa (TAS3, TAS9) (Fig. 1). Some lesions produced by TAS1 nearly girdled the stems (Fig. 2A). Both isolates of S. eucalypti produced characteristic lenticular lesions in stems of all seedlings inoculated (Fig. 2C).

Internal discoloration and the external lesion length were highly correlated ( $r=$ $0.86, P<0.001)$. All internal discoloration lengths associated with the lesions produced by more aggressive isolates, Phoma sp., Endothia gyrosa (all three isolates) (Fig. 3A), and S. eucalypti (two isolates) (Fig. 3B), were longer than external lesion lengths, respectively, while the internal discoloration associated with other fungal isolates was shorter than their external lesions.

Callus developed within 3 to 4 weeks after inoculation in both control wounds and the wounds inoculated with most of the fungi. The majority of wounds in both control seedlings (Figs. 2D and 3C) and in those inoculated with Cytospora eucalypticola, Ceuthospora innumera, D. strigosum, $H$. aff. eucalypti, S. papillatum, S. unicorne, and Zythiostroma sp. (both isolates) were nearly callused over 2 months after inoculation. In contrast, all wounds inoculated with Botryosphaeria sp., Endothia gyrosa (all three isolates), Phoma sp., and $S$. eucalypti (both isolates) were open at this stage. Most wounds inoculated with $P$. neglecta and W. epispora were also open. Seven months after inoculation, none of the lesions produced by Endothia gyrosa (TAS1) had callused-over. However at least two, most often three, wounds on seedlings inoculated with other fungal isolates were completely callused over.

Fungal fruiting bodies were observed on all the lesions produced by Endothia gyrosa, $H$. aff. eucalypti, P. neglecta, Phoma sp., S. eucalypti, S. papillatum, and Zythiostroma sp. 2 months after inoculation. No fruiting bodies were found on lesions produced by the other fungi. With the exception of Cytospora eucalypticola, those fungi that had not produced fruiting bodies at 2 months were sporulating at 7 months. Microscopic examinations showed that all three ascomycetous fungi, Botryosphaeria sp., Endothia gyrosa, and W. epispora, produced anamorphs. Botryosphaeria sp. produced an anamorph with conidiomata containing oneto two-celled pigmented conidia, possibly a 
species of Botryodiplodia or Lasiodiplodia. Orange-colored fruitbodies of anamorph Endothia gyrosa were abundant at the surface of all the lesions produced by inoculating with its teleomorph. W. epispora produced conidia of $H$. aff. eucalypti on all lesions of inoculated seedlings.

The three isolates of Endothia gyrosa were reisolated from all of the wood fragments excised from the stems near the inoculation points. All other fungi producing large lesions (Phoma sp., Botryosphaeria sp., and both isolates of $S$. eucalypti) were reisolated from 32 to $68 \%$ of the fragments, a significantly lower percentage than for Endothia gyrosa isolates. In contrast, the majority of the fungal isolates not producing significantly larger lesions than controls, such as $P$. neglecta, Cytospora eucalypticola, Ceuthospora innumera, Zythiostroma sp. (both isolates), $S$. papillatum, and D. strigosum, were successfully reisolated from 67 to $100 \%$ of the fragments. $H$. aff. eucalypti was only recovered from $4 \%$ of the fragments, although $58 \%$ of the fragments from stems inoculated with its W. epispora teleomorph yielded $H$. aff. eucalypti. $S$. unicorne was reisolated from only $21 \%$ of the fragments.

Pathogenicity of fungi on $E$. globulus seedlings. The pattern of lesion lengths (external and internal) for the different fungal species (Fig. 1) was fairly similar to those observed on E. nitens, although the percentage of stem girdled by these fungi was less than those on E. nitens (all less than $50 \%$, Fig. 1). Those fungi most aggressive on E. nitens, such as Endothia gyrosa, Phoma sp., S. eucalypti (CF39), and Botryosphaeria sp., also were most aggressive on E. globulus (Fig. 1). Reisolation percentages of the fungi from inoculated E. globulus stems ranged from 28 to $100 \%$, and the only fungal species not sporulating on lesions 7 months after inoculation were Cytospora eucalypticola, D. strigosum, and W. epispora.

Despite overall similarity in results, significant differences were observed in host response to some fungi. Phoma sp. produced much shorter external lesions when inoculated on E. globulus than on E. nitens (Fig. 1). Lesions produced by Phoma sp. on $E$. globulus were also significantly $(P \leq$ $0.05)$ shorter than those produced by $S$. eucalypti (CF39), Endothia gyrosa (TAS1), and S. papillatum. Isolates of Cytospora eucalypticola and Ceuthospora innumera, which were not pathogenic on E. nitens, produced lesions significantly longer and with higher percentage of stem girdled than the controls (Fig. 1). Although an isolate of Zythiostroma sp. (ECF147) did not produce lesions significantly longer than the control in both eucalypt species, stem girdling induced by this isolate was significantly greater than the control on $E$. globulus but not $E$. nitens.

Internal discoloration (data not shown) and the external lesion length were also highly correlated $(r=0.74, P<0.001)$. Similar patterns to those on $E$. nitens were found on E. globulus, except that unlike $E$. nitens, the internal discoloration lengths of $P$. neglecta, Zythiostroma sp. (two isolates), Cytospora eucalypticola, and $W$. epispora were longer, not shorter, than their external lesions.
Lesions induced by fungi on E. globulus were less callused than those on E. nitens. All or the majority of the lesions produced by Phoma sp., Endothia gyrosa, S. eucalypti, S. papillatum, Zythiostroma sp. (ECF144), and Botryosphaeria sp. isolates were uncallused, and no callus was observed around the wounds. One or two of
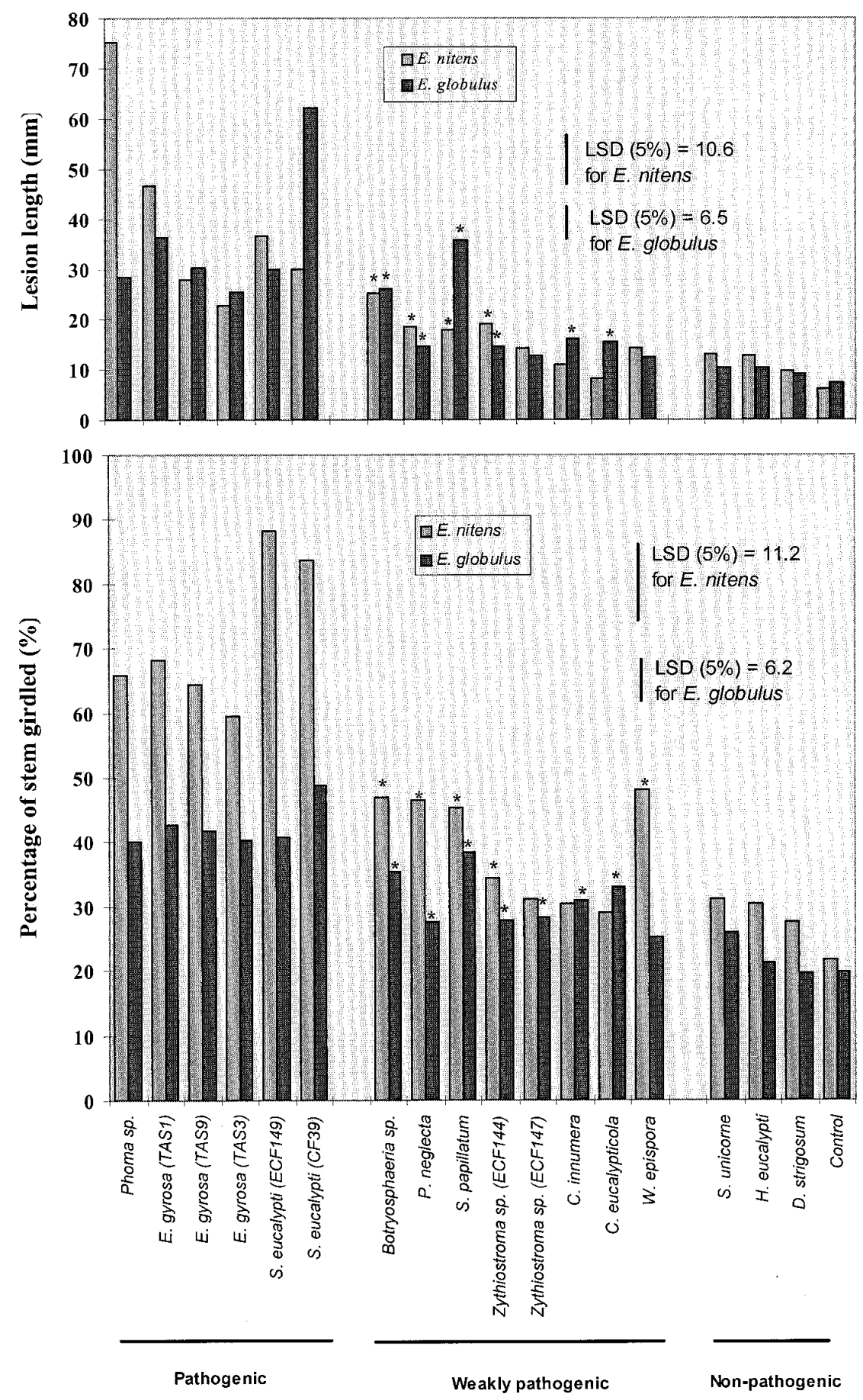

Fungal species (isolates)

Fig. 1. Mean external lesion length and percentage of stem girdled on stems of Eucalyptus nitens and E. globulus seedlings inoculated with 13 fungal species assessed at 7 months. Bars with an asterisk are significantly different from the controls, only marked for weakly pathogenic isolates because all pathogenic isolates were significantly different from the controls and the nonpathogenic were not. 
the five wounds for each isolate with Cytospora eucalypticola, S. unicorne, Zythiostroma sp. (ECF147), Ceuthospora innu$m e r a$, and $P$. neglecta were slightly cal- lused over at 7 months. Only lesions in control treatments, or those inoculated with $D$. strigosum, $H$. aff. eucalypti, and $W$. epispora, were all completely callused over.

\section{DISCUSSION}

Pathogenicity of tested fungal species. The fungal species tested in the study could be classified into three groups based
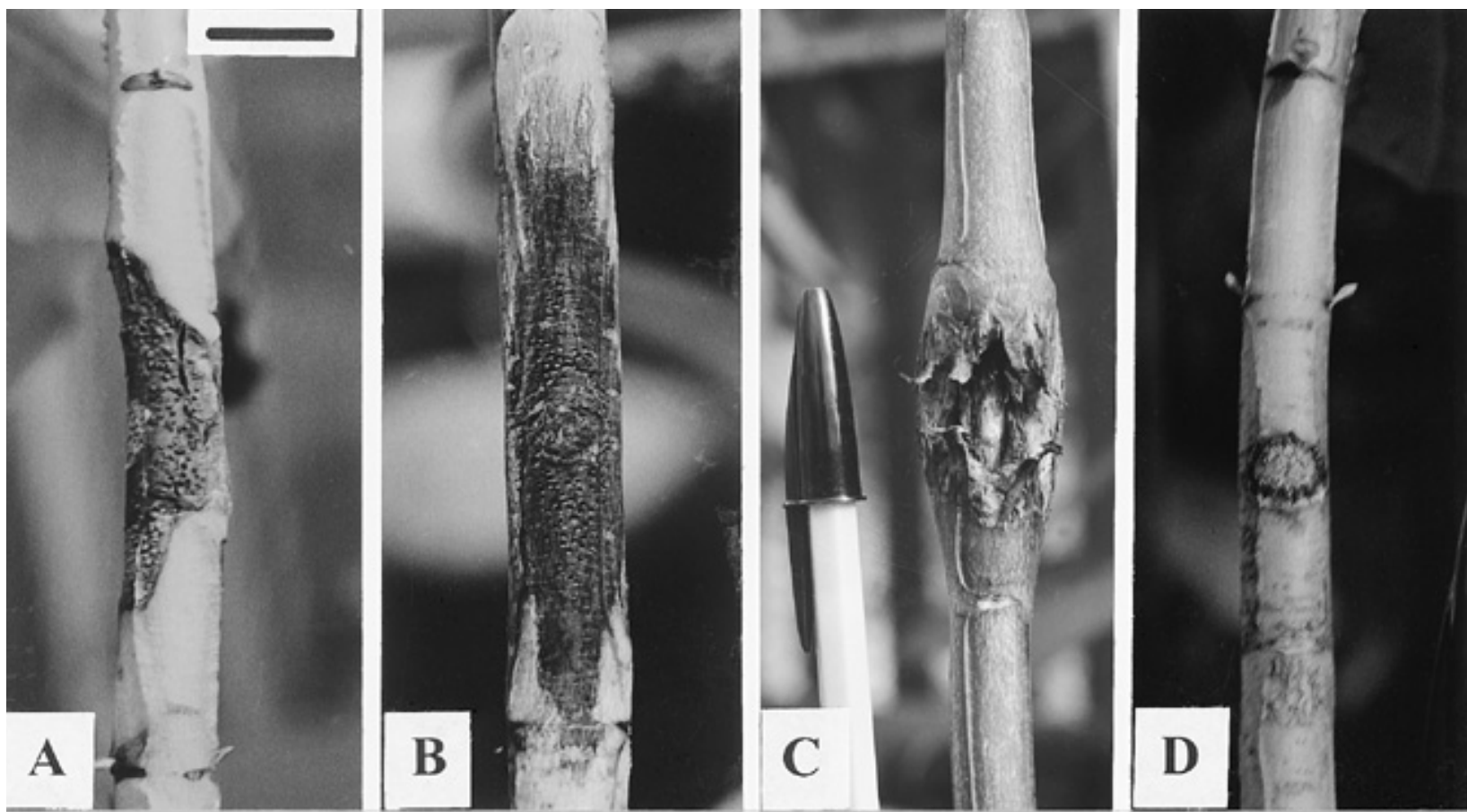

Fig. 2. External lesions produced by stem canker fungi on 12-month-old seedlings of Eucalyptus nitens 7 months after inoculation and a control wound: (A) lesion of seedling inoculated with isolates of Endothia gyrosa (TAS1) (note pycnidia of the fungus produced on the lesion surface); (B) lesion produced by Phoma sp.; (C) lesion produced by Seiridium eucalypti (ECF149); (D) control wound (completely callused over). Bar = $10 \mathrm{~mm}$ for A, B, C, and D.
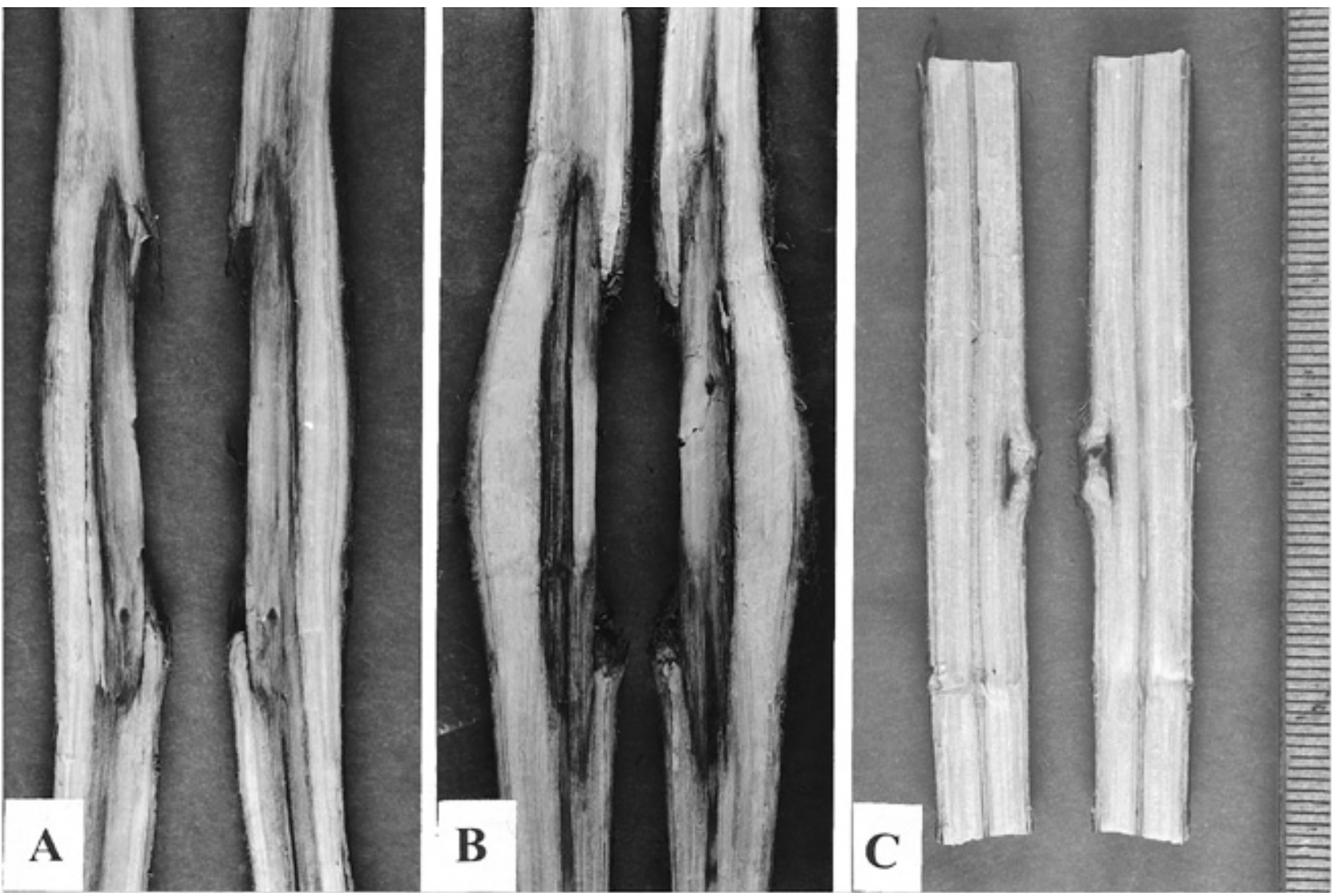

Fig. 3. Longitudinal section showing internal discoloration produced by stem canker fungi on 12-month-old seedlings of Eucalyptus nitens 7 months after inoculation: (A) internal discoloration produced by Endothia gyrosa (TAS1); (B) internal discoloration produced by Seiridium eucalypti (ECF149); (C) control wound. One division in $\mathbf{C}=1 \mathrm{~mm}$ for $\mathbf{A}, \mathbf{B}$, and $\mathbf{C}$. 
on their ability to cause stem canker lesions on seedlings of $E$. nitens and $E$. globulus following artificial inoculation:

1. Pathogenic species, which always produced lesions significantly larger than control wounds on both host species (with the percentage of stem girdled up to or more than $50 \%$ on E. nitens and $40 \%$ on E. globulus; internal discoloration always longer than external lesion lengths): Phoma sp., Endothia gyrosa, and S. eucalypti;

2. Intermediate or weakly pathogenic species, which occasionally caused lesions significantly larger than control wounds on either host species (with the percentage of stem girdled less than $50 \%$ on E. nitens and $40 \%$ on E. globulus; internal discoloration generally shorter than external lesion lengths): Botryosphaeria sp., $S$. papillatum, $P$. neglecta, Zythiostroma sp., Ceuthospora innumera, Cytospora eucalypticola, and W. epispora;

3. Nonpathogenic species that did not produce lesions significantly different (in length or width) from the controls on either host species (with the internal discoloration always shorter than external lesion lengths): D. strigosum, $S$. unicorne, and $H$. aff. eucalypti.

Although it was encountered only once during our previous survey of eucalypt canker fungi in Tasmania (40), the Phoma sp. was investigated because of its association with one large, sunken canker on the main stem of Eucalyptus rubida in the field. Its ability to cause large, sunken lesions and seedling mortality was therefore not unexpected. Other species of the genus Phoma, e.g., P. eucalyptica, have also been reported previously as eucalypt stem canker agents $(1,12)$. Although we hesitate to formally describe our Phoma sp. based on a single isolate, a previous examination of its morphological and cultural characteristics (39) clearly suggests it is an undescribed species of Phoma. In view of its demonstrated pathogenicity, further investigation of its occurrence on E. rubida and other eucalypt species is needed.

Endothia gyrosa was included in the present tests because of its comparatively high frequency of collection and association with eucalypt stem cankers (40). Pathogenicity of Endothia gyrosa on E. nitens and E. globulus adds to previous reports of its pathogenicity on other eucalypts $(11,17,18,34)$.

The isolate of Botryosphaeria sp. induced only small or moderate-sized cankers on seedlings of $E$. nitens and $E$. globulus in this study. It did not produce significantly larger cankers than the controls on 16-year-old trees of E. nitens in field inoculations (39). The identity of this isolate is uncertain. Originally, it was obtained from a stem canker on E. stellulata with crown dieback in New England, New South Wales, and was identified from teleomorph and colony morphology as
Botryosphaeria dothidea (=B. ribis) (37). In our inoculation experiments, it produced lesions with pigmented conidia, the anamorph Botryodiplodia or Lasiodiplodia. $B$. dothidea $(=B$. ribis $)$ is a known stem pathogen of eucalypts in Australia $(9,17,26)$, the state of Florida (2), and South Africa (28), although not recorded in Tasmania. However, B. dothidea does not produce pigmented conidia, but hyaline conidia belonging to the anamorphic genus Dothiorella (27). Only one Botryosphaeria species, B. obtusa, has been recorded on Crataegus, Malus, and Pyrus spp. in Tasmania (20). The anamorph of B. obtusa has pigmented conidia (27) resembling those produced on the lesions by the present Botryosphaeria sp. More work is needed to identify the Botryosphaeria sp. used in this study.

The Tasmanian isolate of $P$. neglecta was a weak canker pathogen but remained viable in lesions, as indicated by successful reisolations (100\% on E. nitens and $88 \%$ on E. globulus). This $P$. neglecta was originally isolated from several healthy bark samples of plantation $E$. nitens in Tasmania (Z. Q. Yuan and C. Mohammed unpublished data). Two other species of the genus Pestalotiopsis have been reported as endophytic on eucalypts. $P$. versicolor was found in healthy twigs of mature E. nitens in Canberra (10), and recently $P$. guepini was isolated from healthy twigs of $E$. grandis in Uruguay (3). Old et al. (18) often recovered Pestalotiopsis from the sapwood of artificially wounded E. sieberi trees. They also isolated Pestalotiopsis from the seedling stems of several Eucalyptus inoculated with other stem fungi. P. neglecta is possibly endophytic in Tasmania, like other Pestalotiopsis species, although it causes blight or spots on leaves and shoots of $E$. globulus and E. grandis in India (24).

$S$. eucalypti has been consistently shown by other workers (43) to be pathogenic when tested on Eucalyptus spp. It was among the most pathogenic of fungi tested in this study based on canker size. Two other Seiridium species, $S$. papillatum recovered in the survey (40) and S. unicorne isolated from Callitris sp. in the Australian Capital Territory (ACT), were included for comparison. Neither $S$. papillatum nor $S$. unicorne proved to be as aggressive as $S$. eucalypti. S. papillatum is a newly described species on eucalypts (41) and was weakly pathogenic on both $E$. nitens and $E$. globulus, while $S$. unicorne never produced lesions different from controls despite its reported pathogenicity on other hosts. $S$. unicorne has been reported as a primary canker pathogen on cypress in Australia (32), Japan (as Monochaetia unicornis) (22), Portugal (36), New Zealand (4), and the United States (as M. unicornis) (5). It causes cankers on artificially wounded shoots of Chamaecyparis lawsoniana and Cupressus sempervirens (29). In Tasmania, it has been recorded on several conifers, including Chamaecyparis, Cupressocyparis, Cupressus, Libocedrus, and Thuja (20). Morphologically, S. unicorne is close to $S$. eucalypti $(32,43)$. The pathogenicities of the three Seiridium species tested in this study support their separation based on other attributes such as morphology and DNA polymorphism (Z. Q. Yuan and C. Mohammed, unpublished data).

Zythiostroma sp. was tested because of the frequency with which it was collected on cankered stems and the strong pathogenic ability demonstrated by a Zythiostroma species isolated from Banksia coccinea in Western Australia (25). The Zythiostroma species isolated from B. coccinea in Western Australia produces large cankers on inoculated seedlings of $B$. coccinea. The Zythiostroma species used in this study was associated with several stem cankers on dead branches (40), but it proved to be weakly pathogenic on $E$. globulus and E. nitens.

Among the weakly pathogenic fungi, Cytospora eucalypticola is the only species that has been previously studied using artificial inoculations. This fungus was found commonly associated with dead branches of stressed trees (40). Similarly to isolates studied in other states of Australia $(9,18)$, the isolate of Cytospora eucalypticola from eucalypts in Tasmania proved to be only weakly pathogenic on seedlings of E. globulus. This fungus was described as a canker pathogen of young E. saligna in South Africa (33).

The isolate of Ceuthospora innumera was collected from dead branches of $E$. nitens. Prior to this study, it was only recorded in Australia as a saprobic on dead wood or causing leaf spots on leaves of several eucalypts (21). Ceuthospora innumera was originally described on dead eucalypt leaves from Tasmania in 1899 (19). The fungus was not pathogenic on seedlings of $E$. nitens but was weakly pathogenic to E. globulus seedlings.

D. strigosum was found for the first time on the dead woody stems of eucalypts in our recent survey (40), although it has been recorded on leaves of Acacia in Australia (38). This isolate of D. strigosum was not pathogenic on seedlings of $E$. nitens or $E$. globulus. This is consistent with earlier reports of the fungus as a common saprophyte on plants of the Gramineae (30).

Although its newly proposed teleomorph W. epispora (42) can be classified as a weak pathogen based on $E$. nitens seedlings, $H$. aff. eucalypti did not produce lesions significantly different from the controls on either of the two eucalypt species tested. Low reisolation percentages from the tissue around inoculation points indicated that the fungus did not become established in living host tissue. $H$. aff. eucalypti was investigated because it was associated with cankers in an E. regnans plantation in Tasmania (40), although 
mainly on senescent branches or dead suppressed branches in the lower part of the crown. H. eucalypti has been reported from elsewhere on leaves or occasionally on small dead twigs $(15,30)$. Most of the other known species of Harknessia also do not appear to be aggressive parasites. Swart (31) also observed that both Harknessia renispora on Melaleuca squarrosa and $H$. uromycoides on Platylobium obtusangulum were found only on leaves already colonized by Seimatosporium spp.

Host susceptibility. Research has already shown that, in artificial inoculation tests, certain eucalypt species are more susceptible to stem canker fungi than others. Yuan (37) tested five species, Botryosphaeria dothidea, Cytospora eucalypticola, Endothia gyrosa, S. eucalypti, and Thyrostroma eucalypti, on 13-month-old seedlings of nine eucalypt species in a glasshouse. Of the tested eucalypts, $E$. cypellocarpa was the most susceptible species to $B$. dothidea, Endothia gyrosa, and S. eucalypti. Old et al. (16) also found that four out of five fungal isolates tested (Endothia gyrosa, Endothiella sp., Diaporthe sp., and Phomopsis sp.) produced the longest lesions on 12-month-old seedlings of E. cypellocarpa. Seedlings of both E. obliqua and E. sieberi were the most resistant to Endothia gyrosa in two separate pathogenicity tests carried out by Old et al. (16) and Yuan (37).

Similar trends on E. nitens (as regards lesion length, percentage of stem girdled, and internal discoloration produced by the fungal species) were observed on $E$. globulus. However, some levels of pathogenicity for the different fungal species or isolates on $E$. globulus are not entirely consistent with those expressed on $E$. $n i$ tens. Certain fungi were more aggressive to E. nitens, such as Endothia gyrosa, Phoma sp., and S. eucalypti (CF39). For example, Phoma sp. produced the longest lesions and killed seedlings of E. nitens, but not of E. globulus, while $S$. papillatum produced lesions much longer on E. globulus than those on E. nitens.

Seedlings of $E$. nitens were inoculated in summer, and seedlings of E. globulus were inoculated in winter in this study. Where different reactions of the two hosts were observed, it is therefore uncertain whether these were due to differences in inherent susceptibility or to the difference in season of inoculation and/or incubation conditions. Further work is needed to determine relative susceptibility of these two host species, as well as the effects of inoculation season and incubation conditions (soil fertility and drainage, drought stress, temperature extremes, freezing, and other weather variables) on canker development and symptom expression.

Potential impact of canker fungi on eucalypt forests. Canker fungi have not been reported as a significant problem in either natural forests or eucalypt planta- tions in Australia, except for an outbreak of Endothia gyrosa canker in an E. nitens plantation observed in 1993 by Wardlaw (35). In both Tasmania and Western Australia, the authors have observed stem breakage in plantation eucalypts associated with insect damage and Endothia gyrosa.

Pathogenicity studies with 11 fungal species from Tasmania have proven that the majority of the fungal species were weak pathogens or saprophytes. They did not produce destructive cankers, such as perennial diffuse or target-shaped cankers, on either seedlings or trees. The majority of the fungal species tested are most likely opportunists and will only cause girdling cankers under conditions unfavorable for the host (23). Endothia gyrosa was comparatively pathogenic in these tests, is commonly associated with crown dieback of natural eucalypts in rural areas of New South Wales (17), and has damaged vigorous plantation eucalypts in Tasmania (35) and plantations in South Africa (6,34). For these reasons, and because it is common across southeastern and western Australia (as Endothiella sp.), Endothia gyrosa is potentially one of the canker fungi more problematic to the eucalypt forest industry in Australia.

\section{ACKNOWLEDGMENTS}

The senior author wishes to thank the University of Tasmania and CSIRO Forestry and Forest Products for his scholarship and North Forest Products for partial financial assistance.

\section{LITERATURE CITED}

1. Azevedo, N. F. d. S. d. 1971. Forest Tree Diseases. Laboratorio de Patologia Forestal Secretaria de Estado da Agricultura, Oeiras, Portugal.

2. Barnard, E. L., Geary, T., English, J. T., and Gilly, S. P. 1987. Basal cankers and coppice failure of Eucalyptus grandis in Florida. Plant Dis. 71:358-361.

3. Bettucci, L., and Alonso, R. 1997. A comparative study of fungal populations in healthy and symptomatic twigs of Eucalyptus grandis in Uruguay. Mycol. Res. 101:10601064.

4. Boesewinkel, H. J. 1983. New records of the three fungi causing cypress canker in New Zealand, Seiridium cupressi (Guba) comb. nov. and S. cardinale on Cupressocyparis and S. unicorne on Cryptomeria and Cupressus. Trans. Br. Mycol. Soc. 80:544-547.

5. Boyce, J. S., and Graves, A. A. 1966. Monochaetia canker on Arizona cypress in Georgia and South Carolina. Plant Dis. Rep. 50:482483.

6. Brits, D., and Grey, D. 1992. A brief field guide to Eucalyptus diseases in South Africa. HL\&H Research, Pietermaritzburg, South Africa.

7. Commonwealth of Australia. 1999. National Plantation Inventory of Australia 1999 tabular update. On-line, Commonwealth of Australia, a June tabular.

8. Conradie, E., Swart, W. J., and Wingfield, M. J. 1990. Cryphonectria canker of Eucalyptus, an important disease in plantation forestry in South Africa. S. Afr. For. J. 152:43-49.

9. Davison, E. M., and Tay, F. C. S. 1983. Twig, branch, and upper trunk cankers of Eucalyptus marginata. Plant Dis. 67:1285-1287.

10. Fisher, P. J., Petrini, O., and Sutton, B. C.
1993. A comparative study of fungal endophytes in leaves, xylem and bark of Eucalyptus nitens in Australia and England. Sydowia 45:338-345.

11. Fraser, D., and Davison, E. M. 1986. Stem cankers of Eucalyptus saligna in Western Australia. Aust. For. 48:220-226.

12. Gibson, I. A. S. 1975. Diseases of Forest Trees Widely Planted as Exotics in the Tropics and Southern Hemisphere. Part I. Important members of the Myrtaceae, Leguminosae, Verbenaceae and Meliaceae. Mycological Institute \& Commonwealth Forestry Institute, Kew, Eng.

13. Hodges, C. S., Reis, M. S., Ferreira, F. A., and Henfling, J. D. M. 1976. O cancro do eucalypto causado por Diaporthe cubensis. Fitopatol. Bras. 1:129-170.

14. Minitab Inc. 1993. MINITAB for Windows. Rel. 9.2. Minitab Inc., State College, PA.

15. Nag Raj, T. R. 1993. Coelomycetous Anamorphs with Appendage-bearing Conidia. Mycologue Publications, Waterloo, Canada.

16. Old, K. M., Dudzinski, M. J., Gibbs, R. J., and Kubono, T. 1993. Stem degrade following harvesting damage. Collaborative research in regrowth forests of East Gippsland between CSIRO and the Victorian Department of Conservation and Natural Resources. Second progress. CSIRO Forestry \& Forest Products, Canberra, Australia.

17. Old, K. M., Gibbs, R., Craig, I., Myers, B. J., and Yuan, Z. Q. 1990. Effect of drought and defoliation on the susceptibility of eucalypts to cankers caused by Endothia gyrosa and Botryosphaeria ribis. Aust. J. Bot. 38:571581.

18. Old, K. M., Murray, D. I. L., Kile, G. A., Simpson, J., and Malafant, K. W. J. 1986. The pathology of fungi isolated from eucalypt cankers in south east Australia. Aust. For Res. 16:21-36.

19. Saccardo, P. A., and Sydow, P. 1902. Sylloge Fungorum 16:1-1291

20. Sampson, P. J., and Walker, J. 1982. An annotated list of plant diseases in Tasmania. Department of Agriculture Tasmania, Hobart, Australia.

21. Sankaran, K. V., Sutton, B. C., and Minter, D. W. 1995. A checklist of fungi recorded on Eucalyptus. Mycol. Pap. 170:1-376.

22. Sasaki, K., and Kobayashi, T. 1975. Resinous canker disease of Cupressaceae caused by Monochaetia unicornis (Cke. et Ell.) Sacc. I Bull. Gov. For. Exp. Stat. 271:27-38 (In Japanese).

23. Schoeneweiss, D. F. 1975. Predisposition, stress, and plant disease. Annu. Rev. Phytopathol. 13:193-211.

24. Sharma, J. K., Mohanan, C., and Florence, E. J. M. 1985. Occurrence of Cryphonectria canker disease of Eucalyptus in Kerala, India Ann. Appl. Biol. 106:265-276.

25. Shearer, B. L., Fairman, R. G., and Bathgate, J. A. 1995. Cryptodiaporthe melanocraspeda canker as a threat to Banksia coccinea on the south coast of Western Australia. Plant Dis. 79:637-641.

26. Shearer, B. L., Tippett, J. T., and Bartle, J. R. 1987. Botryosphaeria ribis infection associated with death of Eucalyptus radiata in species selection trials. Plant Dis. 71:140145 .

27. Sivanesan, A. 1984. The bitunicate ascomycetes and their anamorphs. J. Cramer, Berlin.

28. Smith, H., Kemp, G. H. J., and Wingfield, M. J. 1994. Canker and die-back of Eucalyptus in South Africa caused by Botryosphaeria dothidea. Plant Pathol. 43:1031-1034.

29. Spanos, K. A., Pirrie, A., and Woodward, S. 1997. In vitro expression of resistance responses to Seiridium species in micropropagated shoots of Cupressus sempervirens and 
Chamaecyparis lawsoniana. Can. J. Bot. 75:1103-1109.

30. Sutton, B. C. 1980. The Coelomycetes. CAB International Mycological Institute, Kew, Eng.

31. Swart, H. J. 1972. Australian leaf-inhabiting fungi. III. Observations on Harknessia. Trans. Br. Mycol. Soc. 59:309-311.

32. Swart, H. J. 1973. The fungus causing cypress canker. Trans. Br. Mycol. Soc. 61:71-82.

33. van der Westhuizen, G. C. A. 1965. A disease of young Eucalyptus saligna in Northern Transvaal. J. S. Afr. For. 54:12-16.

34. van der Westhuizen, I. P., Wingfield, M. J., Kemp, G. H. J., and Swart, W. J. 1993. First report of the canker pathogen Endothia gyrosa on Eucalyptus in South Africa. Plant Pathol. 42:661-663.
35. Wardlaw, T. J. 1999. Endothia gyrosa associated with severe stem cankers on plantation grown Eucalyptus nitens in Tasmania, Australia. Eur. J. For. Pathol. 29:199-208.

36. Xenopoulos, S. G. 1991. Pathogenic variability of various isolates of Seiridium cardinale, $S$. cupressi and $S$. unicorne inoculated on selected Cupressus clones and seedlings. Eur. J. For. Pathol. 21:129-135.

37. Yuan, Z. Q. 1989. Mycology and pathology of seed-borne fungi on native Australian trees, and of eucalypt canker fungi. M.Sc. thesis. Xinjiang Agricultural University, Urumqi, P. R. China.

38. Yuan, Z. Q. 1996. Fungi and associated tree diseases in Melville Island, Northern Territory, Australia. Aust. Syst. Bot. 9:337-360.

39. Yuan, Z. Q. 1998. Stem canker diseases of eucalypts in Tasmania. Ph.D. thesis. University of Tasmania, Hobart, Australia.

40. Yuan, Z. Q., and Mohammed, C. 1997. Investigation of fungi associated with stem cankers of eucalypts in Tasmania, Australia. Australas. Plant Pathol. 26:78-84

41. Yuan, Z. Q., and Mohammed, C. 1997. Seiridium papillatum, a new species (mitosporic fungus) described on stems of eucalypts in Australia. Aust. Syst. Bot. 10:69-75.

42. Yuan, Z. Q., and Mohammed, C. 1997 Wuestneia epispora sp. nov. on stems of eucalypts from Australia. Mycol. Res. 101:196-200.

43. Yuan, Z. Q., and Old, K. M. 1995. Seiridium eucalypti, a potential stem canker pathogen of eucalypts in Australia. Australas. Plant Pathol. 24:173-178. 